\title{
Assessment of Nitrogen and Phosphorus in Mangrove Forest Soil at Awat-Awat Lawas Sarawak
}

\author{
Seca Gandaseca ${ }^{1}$, Ahmad Mustapha Mohamad Pazi ${ }^{1}$, Muhammad Nazrin Syafiq Zulkipli ${ }^{2}$, Ahmad \\ Hanafi Hamzah ${ }^{1}$, Pakhriazad Hassan Zaki ${ }^{3}$, Arifin Abdu ${ }^{3}$ \\ ${ }^{1}$ Department of Forest Production, Faculty of Forestry, Universiti Putra Malaysia, UPM Serdang, Selangor, Malaysia \\ ${ }^{2}$ Department of Crops Science, Faculty of Agriculture and Food Science, Universiti Putra Malaysia Bintulu Sarawak Campus, Bintulu, \\ Sarawak, Malaysia \\ ${ }^{3}$ Department of Forest Management, Faculty of Forestry, Universiti Putra Malaysia, UPM Serdang, Selangor, Malaysia
}

\section{Email address:}

seca@upm.edu.my

\section{To cite this article:}

Seca Gandaseca, Ahmad Mustapha Mohamad Pazi, Muhammad Nazrin Syafiq Zulkipli, Ahmad Hanafi Hamzah, Pakhriazad Hassan Zaki, Arifin Abdu. Assessment of Nitrogen and Phosphorus in Mangrove Forest Soil at Awat-Awat Lawas Sarawak. American Journal of Agriculture and Forestry. Vol. 4, No. 5, 2016, pp. 136-139. doi: 10.11648/j.ajaf.20160405.14

Received: November 15, 2015; Accepted: January 6, 2016; Published: October 11, 2016

\begin{abstract}
Despite few studies of forest health and environmental conditions of mangrove forest in Sarawak, the data was not sufficient to facilitate baseline data and direct comparison of mangrove forest health obtained for mangrove forest in Awat-Awat, Lawas, Sarawak. The objectives of the study were to determine the total N and available P concentration in the mangrove forest soil along with the effect of the soil depth on nutrient concentration. Mangrove soil samples were taken from Lawas Division of Sarawak at 0-15 cm and 15-30 cm depths. Selected soil chemical properties as N, P, pH and Soil Cation Exchange Capacity (CEC) were determined using standard methods. As a result, means of selected chemical properties are as follow, 0-30 cm N\% (0.196), $\mathrm{P}(15.59 \mathrm{ppm}), \mathrm{pH}$ in water solution (5.83), $\mathrm{pH}$ in $1 \mathrm{M} \mathrm{KCl}(5.32)$ and $\mathrm{CEC}(27.53 \mathrm{cmol})$ while at $30-50 \mathrm{~cm}, \mathrm{Total} \mathrm{N} \%(0.403), \mathrm{P}$ (6.45 ppm), $\mathrm{pH}$ in water (5.59), $\mathrm{pH}$ in $1 \mathrm{M} \mathrm{KCl} \mathrm{(4.99)} \mathrm{and} \mathrm{CEC} \mathrm{(29.57} \mathrm{cmol).} \mathrm{Conclusion} \mathrm{of} \mathrm{this} \mathrm{study,} \mathrm{soil} \mathrm{depth} \mathrm{has} \mathrm{given}$ significant effects on the soil acidity, total N, available P and CEC with the difference depth. Where top soil contains less nutrient concentration than the bottom soil. The data statistical analysis has shown there are significantly different between the depths of the mangrove soil. Obtained data can be useful for further study of nutrient content and for the rehabilitation of the mangrove forest in another area.
\end{abstract}

Keywords: Total N, Available P, Mangrove Forest, Lawas, Sarawak

\section{Introduction}

Mangroves forests can truly be considered as evolutionary hotspots where terrestrial species have re-adapted to marine life, and marine species have undergone the transition to terrestrial species. In fact, mangroves are salt tolerant trees which evolved from rainforest trees over 50 million years ago [1]. Plant nutrition and the cycling of minerals and trace elements have received less attention in mangrove forests than in other tropical forests. Mangroves, like other tropical trees, have some potential for nutrient loss, but actual losses at the ecosystem level appear to be low.

Mangrove trees and forests exhibit a variety of physiological and biogeochemical mechanisms to reduce nutrient losses via tidal or atmospheric exchange while coping with a salty, waterlogged environment [2]. These mechanisms may include ion retention, translocation, and immobilization in waterlogged soils; high nutrient-use efficiency; litter retention by soil fauna; and slow rates of organic matter decomposition and root turnover. The storage of nutrients in tree biomass is often characterized as a nutrient conserving mechanism in tropical forests [3]. Recent reviews, however, indicate that tropical forests may not store proportionally more nutrients than boreal or temperate trees. Nutrient storage patterns may vary, depending on a variety of factors including soil fertility, species composition, and forest age [4][5]. Mangroves typically have low mineral and trace element concentrations in their leaves, regardless of soil and water 
concentrations [6].

Mangrove ecosystems presently cover an area of about 20 million hectares worldwide. They are the main vegetation type in protected intertidal areas along tropical and subtropical coastlines [7]. As a forest type that affected by tides, soil texture and marine salinity. This forest been acknowledged as one of the most productive ecosystems which grow on sheltered shores and estuaries in the tropics and subtropical area [8].

Furthermore, mangroves also are very well adapted to grow in sea and brackish water. They have roots that typically grow in anaerobic residue and obtain oxygen through aerating tissue which communicates to the air through lenticels on the aerial roots and trunks [9]. Because of the limited data for tropical forests, comparisons with higher latitude forests are difficult. The objectives of this study were to determine the total $\mathrm{N}$ and available $\mathrm{P}$ concentration in the mangrove forest soil and to determine the effect of the soil depth on total $\mathrm{N}$ and available $\mathrm{P}$ concentration in the mangrove forest.

\section{Materials and Methods}

The study was conducted at Awat-Awat Mangrove Forest,
Lawas. Where, Lawas is located in Limbang division in North of Sarawak, Malaysia. Awat-Awat Mangrove Forest appears as a strip with an average width of $80 \mathrm{~m}$ and varies from 50 to $100 \mathrm{~m}$ from sea to landward. Schematic profile of this forest vegetation was made from field observation and eleven mangrove species from family Avicenniaceae, Rhizophoraceae, Combretaceae, Arecaceae, Rhizophoraceae, and Rubiaceae were identified in Awat-Awat mangrove forest. Soil sampling has been done in November 2013 and January 2014 respectively. Sixty-six soil samples were taken at two different depth which are $0-30 \mathrm{~cm}$ and $30-50 \mathrm{~cm}$, in a 0.5 hectare plot using peat auger. Fresh samples were kept in zip lock plastic bag and labeled. The samples were air dried constantly, ground and sieved to pass a $2 \mathrm{~mm}$ sieve. Soil $\mathrm{pH}$ was determined using $1 \mathrm{M} \mathrm{KCl}$ and water based on the method of Tan [10]. Leaching method by Cottenie [11] were used to determine soil Cation Exchange Capacity (CEC). Total nitrogen was determined by using the Kjeldahl method and available phosphorus was determined using Mehlich's Double Acid and the Blue Method of Bray and Kurtz. The obtained data were analyzed using Statistical Analysis System (SAS) Version 9.2 and LSD test were used to test the significances of soil chemical properties between the locations.

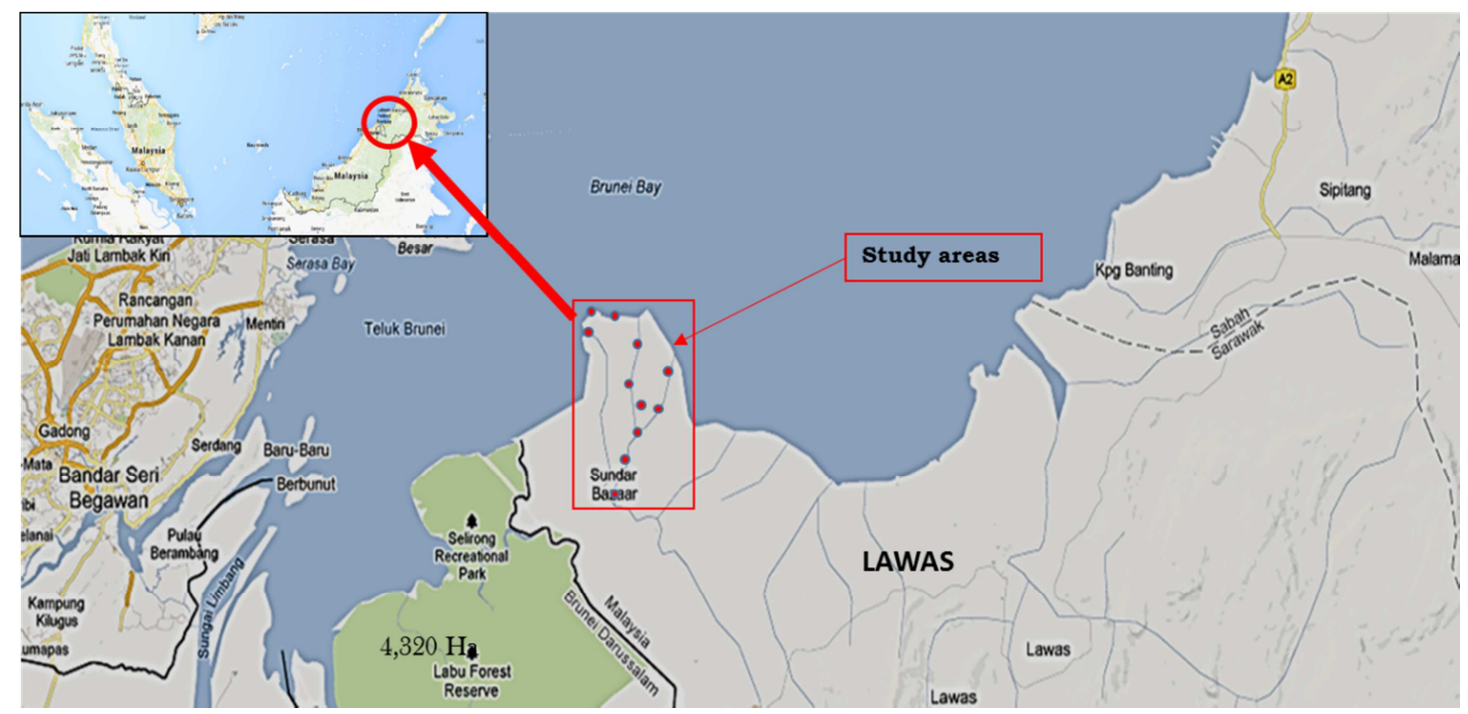

Figure 1. Location of the study areas in Awat-Awat Mangrove Forest Lawas, Sarawak Malaysia.

\section{Result}

Based on Table 1, shows the comparison of nitrogen and phosphorus between the stations on two different depths ( $0-30$ $\mathrm{cm}$ and $30-50 \mathrm{~cm}$ ). The means comparison was test using Fisher's least significance difference (LSD) test. Result of means comparison of total $\mathrm{N}$ in top soil was showed significant different between the stations except total $\mathrm{N}$ in station $\mathrm{T} 2, \mathrm{~T} 3$ and $\mathrm{T} 5$ has recorded no significant different. The highest of total $\mathrm{N}$ in top soil has obtained in $\mathrm{T} 6=0.196^{\mathrm{a}} \%$. While, total $\mathrm{N}$ in bottom soil was recorded highest in $\mathrm{T} 2=0.403^{\mathrm{a}} \%$ and mean comparison was showed significant different between the stations.

In phosphorus concentration, top soil was recorded highest at station $\mathrm{T} 11=15.59^{\mathrm{a}} \mathrm{ppm}$ and the means comparison of phosphorus between the station was showed significant different. While, available of $\mathrm{P}$ in bottom soil was recorded highest at station $\mathrm{T} 11=6.450^{\mathrm{a}} \mathrm{ppm}$ and the means comparison of phosphorus between stations was showed significant different.

Based on Table 2, shows soil $\mathrm{pH}$ in water and $1 \mathrm{M} \mathrm{KCl}$, the range of $\mathrm{pH}$ at is 3.06 to 5.83 and show it's in acidic condition. However, the highest $\mathrm{pH}$ in water in top soil was recorded at station $\mathrm{T} 10=5.83^{\mathrm{a}}$ and the means comparison of the $\mathrm{pH}$ in water was showed significant different among the stations. While, $\mathrm{pH}$ in water in bottom has obtained highest in station $\mathrm{T} 11=5.59^{\mathrm{a}}$ and the means comparison of the $\mathrm{pH}$ in water in bottom soil was showed significant different between the stations. 
In $\mathrm{pH}$ in $1 \mathrm{M} \mathrm{KCl}$ in top soil was obtained highest at stations $\mathrm{T} 10=5.32^{\mathrm{a}}$ and the means comparison of $\mathrm{pH}$ in $1 \mathrm{M} \mathrm{KCl}$ was showed significant different between the stations. While, for $\mathrm{pH}$ in $1 \mathrm{M} \mathrm{KCl}$ in bottom soil was obtained highest at station $\mathrm{T} 11=4.99^{\mathrm{a}}$ and $\mathrm{T} 10=4.98^{\mathrm{a}}$. The means comparison was showed no significant different between station T11 and T10.

Based on Figure 2 shows the trend of cation exchange capacity between stations in 2 different depths. The highest of CEC was obtained at the stations T6 and T1. In term of depth, the highest of CEC at topsoil is obtained in station T6 and the CEC in the bottom soil also recorded at station T6. Based on Figure 3, shows the phosphorus concentrations in two different soil depth which are $0-30 \mathrm{~cm}$ and $30-50 \mathrm{~cm}$. The available of phosphorus is highest at bottom soil and lower at the top soil. The means comparison has obtained significant difference among the depths. Moreover, Figure 4 shows a nitrogen concentration in two difference soil depths and bottom soil has obtained highest in depth 2 . The means comparison was showed significant different between depth 1 and depth 2 .

Table 1. Comparison of nitrogen and phosphorus by stations.

\begin{tabular}{|c|c|c|c|c|}
\hline \multirow{3}{*}{ Station } & \multicolumn{4}{|c|}{ Soil Depths } \\
\hline & \multicolumn{2}{|c|}{ Top Soil $(0-30$ cm) } & \multicolumn{2}{|c|}{ Bottom Soil $(30-50 \mathrm{~cm})$} \\
\hline & $\mathbf{N}(\%)$ & $P(p p m)$ & $\mathbf{N}(\%)$ & $P(\mathbf{p p m})$ \\
\hline $\mathrm{T} 1$ & $0.107^{\text {bcde }}$ & $6.023^{\text {cde }}$ & $0.266^{\mathrm{ab}}$ & $2.470^{\operatorname{defg}}$ \\
\hline $\mathrm{T} 2$ & $0.149^{\mathrm{abc}}$ & $7.793^{\mathrm{c}}$ & $0.403^{\mathrm{a}}$ & $3.590^{\mathrm{bcd}}$ \\
\hline $\mathrm{T} 3$ & $0.154^{\mathrm{abc}}$ & $6.010^{\text {cde }}$ & $0.177^{\mathrm{ab}}$ & $3.020^{\text {cdef }}$ \\
\hline $\mathrm{T} 4$ & $0.159^{\mathrm{ab}}$ & $4.500^{\mathrm{ef}}$ & $0.175^{\mathrm{ab}}$ & $1.840^{\mathrm{efg}}$ \\
\hline T5 & $0.149^{\mathrm{abc}}$ & $10.490^{\mathrm{b}}$ & $0.117^{\mathrm{b}}$ & $4.750^{\mathrm{b}}$ \\
\hline T6 & $0.196^{\mathrm{a}}$ & $5.150^{\mathrm{de}}$ & $0.154^{\mathrm{ab}}$ & $1.190^{\mathrm{g}}$ \\
\hline $\mathrm{T} 7$ & $0.159^{\mathrm{ab}}$ & $6.690^{\mathrm{cd}}$ & $0.126^{\mathrm{b}}$ & $3.360^{\mathrm{bcd}}$ \\
\hline $\mathrm{T} 8$ & $0.131^{\mathrm{bcd}}$ & $7.290^{\mathrm{c}}$ & $0.140^{\mathrm{b}}$ & $4.510^{\mathrm{bc}}$ \\
\hline T9 & $0.093^{\mathrm{de}}$ & $7.130^{\mathrm{c}}$ & $0.327^{\mathrm{ab}}$ & $3.560^{\mathrm{bcd}}$ \\
\hline $\mathrm{T} 10$ & $0.084^{\text {cde }}$ & $3.210^{\mathrm{f}}$ & $0.168^{\mathrm{ab}}$ & $1.570^{\mathrm{fg}}$ \\
\hline $\mathrm{T} 11$ & $0.065^{\mathrm{e}}$ & $15.59^{\mathrm{a}}$ & $0.112^{\mathrm{b}}$ & $6.450^{\mathrm{a}}$ \\
\hline
\end{tabular}

* Different alphabets within a row indicate significant different of mean nitrogen and phosphorus between soil depths using (LSD)

Table 2. Soil $\mathrm{pH}$ in water and $\mathrm{KCl}$ of Awat-Awat Mangrove Forest Lawas, Sarawak.

\begin{tabular}{|c|c|c|c|c|}
\hline \multirow{2}{*}{ Stations } & \multicolumn{2}{|c|}{ pH in Water } & \multicolumn{2}{|c|}{$\mathrm{pH}$ in $1 \mathrm{M} \mathrm{KCl}$} \\
\hline & $(0-30 \mathrm{~cm})$ & $(30-50 \mathrm{~cm})$ & $(0-30 \mathrm{~cm})$ & $(30-50 \mathrm{~cm})$ \\
\hline $\mathrm{T} 1$ & $3.45^{\mathrm{f}}$ & $3.33^{i}$ & $3.12^{\mathrm{i}}$ & $3.06^{\mathrm{fg}}$ \\
\hline $\mathrm{T} 2$ & $4.09^{e}$ & $3.79^{\mathrm{h}}$ & $3.12^{\mathrm{i}}$ & $4.01^{\mathrm{d}}$ \\
\hline $\mathrm{T} 3$ & $5.45^{\mathrm{c}}$ & $4.34^{\mathrm{e}}$ & $5.05^{\mathrm{c}}$ & $3.98^{\mathrm{d}}$ \\
\hline $\mathrm{T} 4$ & $4.08^{e}$ & $5.37^{\mathrm{b}}$ & $3.88^{\mathrm{g}}$ & $4.93^{\mathrm{ab}}$ \\
\hline $\mathrm{T} 5$ & $4.38^{d}$ & $3.96^{\mathrm{f}}$ & $4.08^{e}$ & $3.61^{\mathrm{e}}$ \\
\hline T6 & $3.52^{f}$ & $3.54^{\mathrm{h}}$ & $3.26^{\mathrm{h}}$ & $2.99^{\mathrm{g}}$ \\
\hline $\mathrm{T} 7$ & $3.53^{\mathrm{f}}$ & $3.53^{\mathrm{h}}$ & $3.28^{\mathrm{h}}$ & $3.13^{\mathrm{f}}$ \\
\hline $\mathrm{T} 8$ & $5.64^{b}$ & $5.25^{\mathrm{c}}$ & $5.22^{\mathrm{b}}$ & $4.81^{b}$ \\
\hline T9 & $4.33^{d}$ & $4.44^{\mathrm{d}}$ & $4.01^{\mathrm{f}}$ & $4.67^{\mathrm{c}}$ \\
\hline $\mathrm{T} 10$ & $5.83^{\mathrm{a}}$ & $5.41^{b}$ & $5.32^{\mathrm{a}}$ & $4.98^{\mathrm{a}}$ \\
\hline $\mathrm{T} 11$ & $5.49^{c}$ & $5.59^{\mathrm{a}}$ & $4.99^{c}$ & $4.99^{\mathrm{a}}$ \\
\hline
\end{tabular}

* Different alphabets within a row indicate significant different of mean of $\mathrm{pH}$ between soil depths using (LSD)

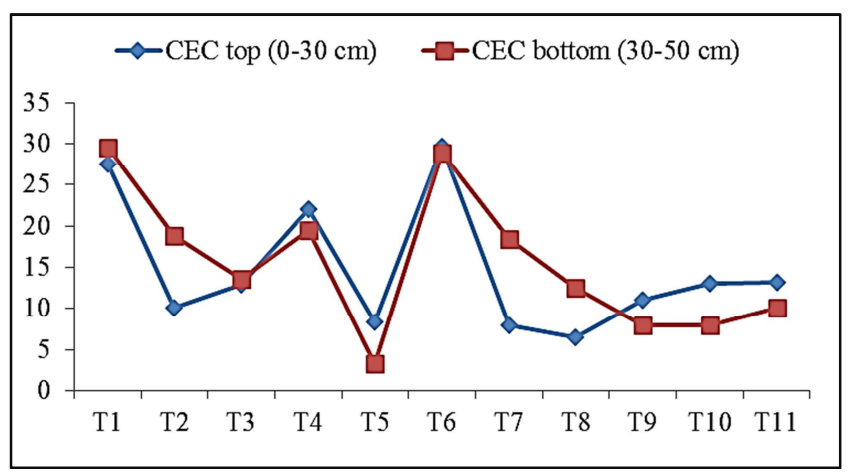

Figure 2. Cation exchange capacity between stations.

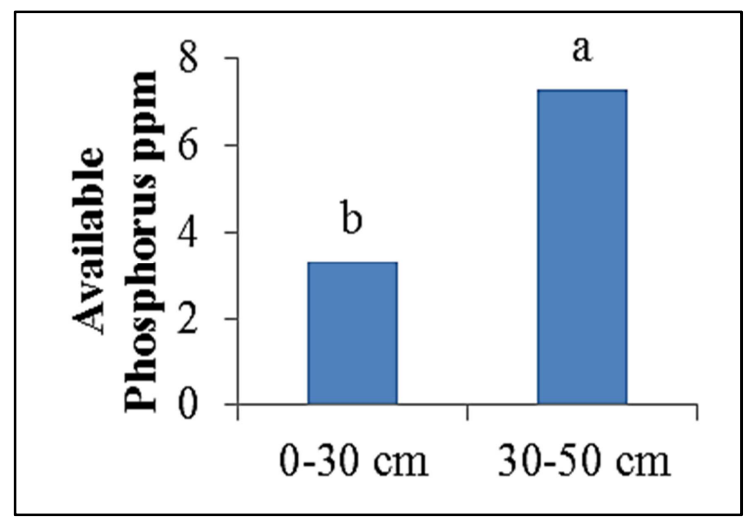

Figure 3. Phosphorus concentrations in two soil depth. The difference is indicated by the different letter as the mean tested with the LSD mean comparisons.

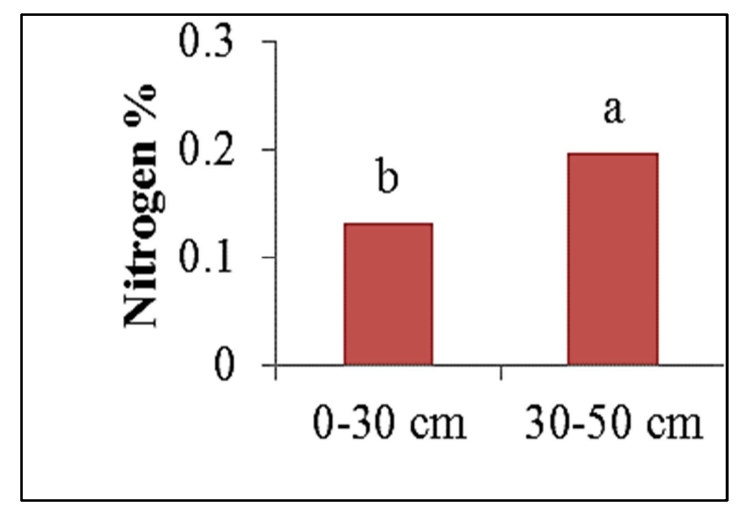

Figure 4. Nitrogen concentration in two difference soil depth. the difference is indicated by the different letters as the mean tested with the LSD mean comparisons.

\section{Discussion}

Based on Figure 3 and Figure 4, soil depths causes the different in nutrient concentration as the top soil become leached as the tidal or rain water comes to contact with the mangrove forest soil. There was a significant loss of nitrogen and phosphorus from the soil because the flow of water [12]. The flow of the water causes the nutrient of the soil become leached through the soil as it. Leaching alone removes a number of substances and can produce high levels of dry organic matter (DOM) [13].

Based on Figure 3, P is the most noticeable in changes as the 
result shows the top soil is less concentration of $\mathrm{P}$ than the bottom soil. $\mathrm{P}$ is the most thoroughly leached element with up to $95 \%$ of the available $\mathrm{P}$ being removed in a very short time [14]. The $\mathrm{N}$ also show the loss of nutrient as the soil higher as the top soil also a lack of concentration than the bottom soil as in Figure 4. But some site may have more nitrogen at the top soil as they receive less tidal or the canopy is large enough to prevent water erosion toward the recycled nutrient as the litter fall of the tree does not wash away by the tidal and water runoff.

Mangrove trees are adapted to the less concentration of nutrient as they were adapted towards such environment. Experiments with fertilization by Onuf [15] suggest that the growth of mangrove trees is constrained by insufficient nutrient supplies to show that mangrove forest is will live with a scarce source of nutrient and rapid growth if fertilizer is applied to them.

The trend for $\mathrm{pH}$ and available $\mathrm{P}$ are inversely proportional (Table 1 and Table 2). The available $\mathrm{P}$ was increased as the $\mathrm{pH}$ of the soil increased either when the soil $\mathrm{pH}$ was tested with water or $\mathrm{KCl}$. In comparison $\mathrm{P}$ content values were much erratic, where a $\mathrm{P}$ content value varied for some site but still some site still in parallel with the trend of its corresponding $\mathrm{pH}$.

Based on Figure 2, the CEC level was different at the upper depth and the value decreased when goes deeper except for the sites T4, T5, T9, T10, and T11. Soils with high CEC could have low cation nutrient fertility. This could happen when the soils contain non-nutrient cations such as aluminium or hydrogen. The significant difference of the CEC in soil maybe due to dominant species such as Sonneratia alba, Sonneratia caseolaris, Rhizophora mucronata and others. These species contribute to high litter fall on the forest floor which trapped by its dense and large roots during tidal inundation. The decomposition takes places induced by microorganisms lead to high carbon accumulates and $\mathrm{H}^{+}$generated contributed to soil acidity. A similar observation was reported by Rambok [16] for $\mathrm{pH}, \mathrm{CEC}, \mathrm{N}$ and $\mathrm{P}$. The same trend also can be seen at the site of T4, T5, T9, T10 and T11.

\section{Conclusion}

Mangrove forest is adapted toward the lack of soil Nitrogen and Phosphorus of the mangrove forest soil. Soil depth has significant effects on the selected chemical properties, i.e., N, $\mathrm{P}, \mathrm{pH}$ and CEC. Topsoil contains less nutrient concentration than the bottom soil. The data obtained from this study can be used for further analysis on other nutrient content and also for the rehabilitation of the mangrove forest in another area.

\section{Acknowledgements}

This research was supported by Universiti Putra Malaysia through the Research Grant Scheme (RUGS). Thanks to staff of Universiti Putra Malaysia Bintulu Sarawak Campus for their help and support.

\section{References}

[1] Giri, C., E. Ochieng, L. L. Tieszen, Z. Zhu, A. Singh, T. Loveland, J. Masek and Duke, N. 2010. Status and Distribution of Mangrove Forests of the World Using Earth Observation Satellite Data. Journal of Global Ecology and Biogeography, pp. 1-6.

[2] Ball, M. C. 1988. Ecophysiology of Mangroves. Trees, 2:129-142.

[3] Golley, F. B., McGinnis, J. T., Clements, R. G. Child, G. I. and Duever, M. I. 1975. Mineral Cycling in a Tropical Moist Forest Ecosystem. University of Georgia Press, Athens. pp. 248.

[4] Drechsel, P and Zech, W. 1991. Foliar Nutrient Levels of Broad-Leaved Tropical Trees: A Tabular Review. Plant and Soil, 131: 29-46.

[5] Chapin, F. S. 1980. The Mineral Nutrition of Wild Plants. Annual Review of Ecology Systems, 11: 233-260.

[6] Lacerda, L. D., Carvalho, C. E., Tanizaki, K. F., Ovalle, A. R. and Rezende, C.E. 1993. The Biogeochemistry and Trace Metals Distribution of Mangrove Rhizospheres. Biotropica, 25: 252-257.

[7] English, S., Wilkinson, C. and Baker V. 1994. Mangrove Ecosystems. In Survey Manual for Tropical Marine Resources. ASEAN-Australia Marine Science Project: Living Coastal Resources, pp. 119-194.

[8] Gandaseca, S., Noraini R., Johin N., and Chandra I.A. 2011. Status of Water Quality Based On the Physico-Chemical Assessment on River Water at Wildlife Sanctuary Sibuti Mangrove Forest, Miri Sarawak. American Journal of Environmental Sciences, 7 (3): 269-275.

[9] Lai, H. C., Teas, H. J., Pannier, F. and Baker, J. M. 1993. Biological Impact of Oil Pollution: Mangrove. International Petroleum Industry Environmental Conservation Association (IPIEACA), 4.

[10] Tan, K. H. 2005. Soil sampling preparation and analysis. 2nd Ed., Taylor and Francis, New York, pp. 623.

[11] Cottenie, A., 1980. Soil and Plant Testing as a Basis of Fertilizer Recommendation. 1st Edn. Food and Agriculture Organization of the United Nations, Rome, pp. 100.

[12] Kaly, U. L., Eugelink, G. and Robertson, A. I. (1997). Soil Conditions In Damaged. North Queensland Mangroves. Estuaries, 2: 291-300.

[13] Benner, R., Fogel M. L., Sprague E. K., and Hodson R. E. 1987. Depletion of $13 \mathrm{C}$ in Lignin And its Implications for Stable Carbon Isotope Studies. Nature, 329: 708-7 10.

[14] Oelkers, E. H. and Valsami-Jones, E. 2008. Phosphate Mineral Reactivity and Global Sustainability. Elements, 4: 83-88.

[15] Onuf, C. P., Teal, J. M. and Valiela. I. 1977. Interactions of Nutrients, Plant Growth and Herbivory In A Mangrove Ecosystem. Ecology, 58: 514-526.

[16] Rambok, E. Seca, G., Osumanu H. A. and Nik Muhamad A. M. 2010. Comparison of Selected Soil Chemical Properties of Two Different Mangrove Forests in Sarawak. American Journal of Environmental Sciences, 6 (5): 438-441. 